\title{
Short Communication: \\ Variation in chemical constituent of Styrax sumatrana wood growing at different cultivation site in North Sumatra, Indonesia
}

\author{
APRI HERI ISWANTO', ${ }^{1,}$, YENNI SUHAIDA SIREGAR ${ }^{1}$, ARIDA SUSILOWATI2, ATMAWI DARWIS ${ }^{3}$, \\ RUDI HARTONO ${ }^{1}$, BASUKI WIRJOSENTONO ${ }^{4}$, HENTI HENDALASTUTI RACHMAT ${ }^{5}$, ASEP HIDAYAT ${ }^{5}$, \\ WIDYA FATRIASARI ${ }^{6}$ \\ ${ }^{1}$ Department of Forest Product, Faculty of Forestry, Universitas Sumatera Utara. Jl. Tri Dharma Ujung No 1, Kampus USU Padang Bulan, Medan, North \\ Sumatra, Indonesia. Tel./fax.: +62-61-8220605. `email: apriheri@yahoo.com \\ ${ }^{2}$ Department of Silviculture, Faculty of Forestry, Universitas Sumatera Utara. Jl. Tri Dharma Ujung No 1, Kampus USU Padang Bulan, Medan 20155, \\ North Sumatra, Indonesia \\ ${ }^{3}$ Department of Chemistry, Faculty of Mathematics and Natural Sciences, Universitas Sumatera Utara. Jl. Tri Dharma Ujung No 1, Kampus USU Padang \\ Bulan, Medan 20155, North Sumatra, Indonesia \\ ${ }^{4}$ School of Life Sciences and Technology, Institut Teknologi Bandung. Gedung Labtex XI, Jalan Ganesha 10, Bandung 40132, West Java, Indonesia \\ ${ }^{5}$ Forest Research and Development Center. Jl. Raya Gunung Batu No. 5, Bogor 16118, West Java, Indonesia \\ ${ }^{6}$ Research Center for Biomaterials, Indonesian Institute of Sciences. Jl. Raya Jakarta-Bogor No.Km 46, Cibinong, Bogor 16911, West Java, Indonesia
}

Manuscript received: 25 October 2018. Revision accepted: 25 January 2019.

\begin{abstract}
Iswanto AH, Siregar YS, Susilowati A, Darwis A, Hartono R, Wirjosentono B, Rachmat HH, Hidayat A, Fatriasari W. 2019. Variation in chemical constituent of Styrax sumatrana wood growing at different cultivation site in North Sumatra, Indonesia. Biodiversitas 20: 448-452. Kemenyan Toba (Styrax sumatrana) is known as endemic resin-producing trees that naturally grow in North Sumatra and distributed throughout five districts within the province. Different growing site may constitute to different characteristics of the species, e.g. morphological differences, chemical constituent, bioactive substances, etc. Different characteristics of wood chemical constituent are an important factor determining further utilization and potential use of wood in wider spectrums. Information about wood chemical constituent of Styrax sumatrana growing from different site has not been determined yet. Therefore, the objective of this research was to analyze the characteristics of chemical constituent of Styrax sumatrana wood originated from North Tapanuli and Pakpak Bharat according to axial direction of stem (bottom, middle, and top). Chemical properties such as hollocelulose, $\alpha$-cellulose, hemicellulose, Acid Soluble Lignin (ASL), acid insoluble lignin (AIL), and non-structural component (extractive content in ethanol benzene 1: 2 and ash content) were observed. Results showed that different growth location would yield in different wood chemical constituent. The wood chemical constituent from North Tapanuli and Pakpak Bharat were 52.72 and 69.80\% (hollocelulose), 25.94 and $39.87 \%$ ( $\alpha$-cellulose), 26.78 and 29.92\% (hemicellulose), 5.49 and 4.33\% (Acid Soluble Lignin), 4.37 and 20.43\% (Acid-Insoluble Lignin), 10.95 and $2.42 \%$ (extractive content), 1.37 and $0.8 \%$ for ash content.
\end{abstract}

Keywords: Chemical constituent, North Tapanuli, Pakpak Bharat, Styrax sumatrana

\section{INTRODUCTION}

Styrax sumatrana is one of the most popular resins originated from North Sumatra Province, Indonesia. Kemenyan trees grow naturally in North Sumatra and can be abundantly found in District of North Tapanuli, Humbang Hasundutan, Papak Bharat, Toba Samosir, and Dairi. Among those areas of distribution, North Tapanuli is known as the biggest producer of Kemenyan resin in North Sumatra. Resin produced by the species provides many uses such as materials for pharmaceuticals, preservatives, perfumes, cosmetics, aromatherapy, incense, and a mixture of clove cigarettes (Widyastuti 1989).

Previous study related to Kemenyan plants from North Sumatra have been carried out by several researchers. Iswanto et al. (2016), and Pasaribu et al. (2013) conducted a study of the physical and mechanical properties of Kemenyan wood. While the potency of it's resin as antioxidant has been reported by Hidayat et al. (2018).
Furthermore, Kiswandono et al. (2016) carried out a study of cinnamic acid content of kemenyan resin originated from North Tapanuli, while study focusing on the phylogenetic study of kemenyan grown in North Sumatra has been reported by Susilowati et al. (2017a). Furthermore, the genetic structure of the endemic Styrax sumatrana has also been determined (Rachmat et al. 2017). The macrocutting technique as one of potential propagations for the species has also been reported (Susilowati et al. 2017b). Furthermore, researches on morphological aspect, flowering and fruiting phenology of kemenyan plant also have been reported (Kholibrina et al. 2018; Susilowati et al. 2018).

The genetic study of this species based on population origin showed that Humbang Hasundutan, North Tapanuli, and Pakpak Bharat own their unique haplotype (Rachmat et al. 2017). Field survey also indicated that there was morphological characteristic found between Kemenyan Toba growing at North Tapanuli, Humbang Hasundutan, 
and Pakpak Bharat. However, information on chemical constituent of Kemenyan Toba growing in North Sumatra currently has not been available yet. Differences observed in their morphological character, and genetic identity may consider the reflection of different chemical composition from its wood. Study by Blankenhorn et al. (1983) found that growing site would affect the differences in chemical composition of poplar woods. Another result by Zhang et al. (2015) found out that chemical constituent of any particular wood is affected by several factors such as site origin and genetic identity. This study was conducted to fill in the gap for the information of chemical constituent of Kemenyan Toba wood based on its site origin.

Study on the variation of chemical constituent in certain wood is important especially for further use of the utilization of unproductive timber. When Kemenyan producing trees grow too old and no longer productive for its resin production, local people usually cut the trees and use the wood only for firewood. This is due to the lack of information of wood utilization and wood characteristics of this species (Pasaribu et al. 2013). Chemical properties of wood are needed as baseline knowledge for further or potential utilization of Kemenyan wood. The objective of this study was to analyze the chemical constituents of cell wall and extractive content of Kemenyan Toba wood cultivated in North Tapanuli and Pakpak Bharat.

\section{MATERIALS AND METHODS}

\section{Materials}

Samples were collected from Kemenyan Toba (Styrax sumatrana) tree originated from North Tapanuli and Pakpak Bharat District. Wood samples were ground into sawdust as seen in Figure 1.

\section{Methods}

Samples preparation

Kemenyan wood from bottom, middle and top position of the stem was ground into powder as shown in Figure 1. Afterward, the wood powder was measured its moisture content and this shall not be exceeding 14\%. The methods for samples preparation were in accordance with TAPPI T $264 \mathrm{~cm}-07$.

\section{Analysis of wood chemical properties}

Wood chemical analysis was observed based on cellulose, hemicellulose, lignin, and extractive content. The observation was conducted using previous research and standard. Lignin content was measured using Acid Lignin Insoluble (AIL) and Acid Soluble Lignin (ASL) analysis based on LAP NREL 003 standard. Holoellulose was analyzed based on Paper Trade J by Wise et al. (1946), while $\alpha$-Cellulose analysis using CRC Press methods according to Rowell (2005). The extractive content was measured based on extractive content in (1: 2) Ethanol Benzene refers to TAPPI T $204 \mathrm{~cm}-97$. The ash contents analysis according to TAPPI T 211 om-02. The observation data then classified refers to Anonim (1976) as shown in Table 1.

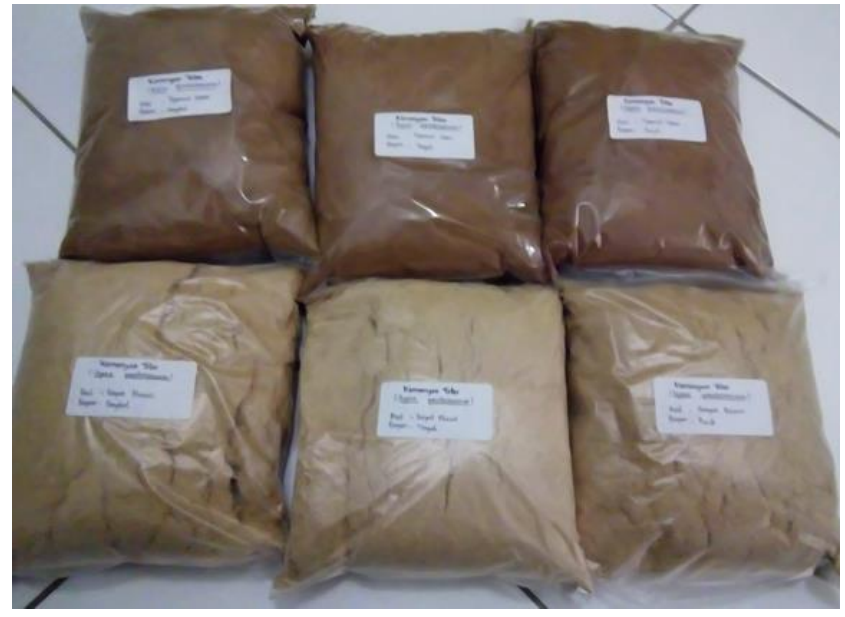

Figure 1. Kemenyan sawdust sample collected from North Tapanuli (above) and Pakpak Bharat Districts, North Sumatra, Indonesia (bellow)

Table 1. Chemical constituent of hardwood

\begin{tabular}{lccc}
\hline \multirow{2}{*}{ Chemical constituent } & \multicolumn{3}{c}{ Classification } \\
\cline { 2 - 4 } & High & Middle & Low \\
\hline Cellulose (\%) & $>45$ & $40-44$ & $<40$ \\
Lignin (\%) & $>33$ & $18-32$ & $<18$ \\
Pentosan (\%) & $>24$ & $21-24$ & $<21$ \\
Extractive content (\%) & $>3$ & $2-3$ & $<2$ \\
Ash content (\%) & $>6$ & $0.22-6$ & $<0.22$ \\
\hline
\end{tabular}

\section{RESULTS AND DISCUSSION}

\section{Wood chemical constituents}

Acid Soluble Lignin (ASL) and Acid-Insoluble Lignin (AIL)

Lignin is one of the second largest substances in wood with a percentage ranging from 17 to $32 \%$ (Casey 1960). Fengel and Wegener (1984) stated that high lignin content is caused by low holocellulose content. The acid soluble lignin and acid insoluble lignin value of Kemenyan wood from North Tapanuli and Pakpak Bharat were shown in Figure 2.

Based on Figure 2, ASL and AIL content of Kemenyan wood have different value and trend between the site. According to the axial direction, ASL and AIL content of Kemenyan wood from Pakpak Bharat decreased from bottom to the top. Meanwhile, for kemenyan wood from North Tapanuli, it showed the opposite trend. The higher lignin content at the top position according to Fengel and Wegener (1984) is due to the fact that top of stem contains more early wood which contains more lignin and less cellulose when compared to latewood. The tendency of increasing lignin content at the top of stem was similar to research conducted by Yunanta et al. (2014) and Latib et al. (2014). According to Easty and Thompson (1991), Akiyama et al. (2005) that ASL content in hardwood ranged from 3 to $5 \%$. Meanwhile, the AIL content of kemenyan wood in this study ranged between of 3.69 to $6.07 \%$. 


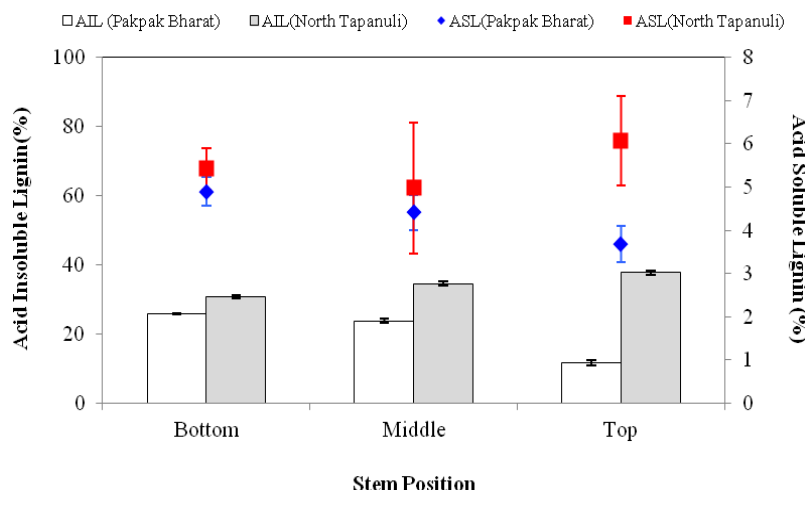

Figure 2. Lignin content of Kemenyan from North Tapanuli and Pakpak Bharat Districts, North Sumatra, Indonesia based on stem position

Lignin compounds have similar function with cellulose. It gives strength to cells because in wood these compounds are present in each layer of cell wall and middle lamella in the cell wall (Haygreen and Bowyer, 1982). According to Table 1, lignin content value of this study from Pakpak Bharat was $20 \%$ in the medium category and $34 \%$ in North Tapanuli meaning as in the high category. The lower content of lignin component from the sample originated from Pakpak Bharat might because of its landscape texture. Pakpak Bharat is much more mountainous and hilly. This finding was supported by previous statement from Stout et al. (2014) who stated that lignin slightly increased on the mountainous site compared to productive site.

Lignin content of plant was influenced by various factors. Poisa et al. (2011) stated that lignin content influenced by the interaction of various factors: when the samples were taken, the sowing period, the variety and the $\mathrm{N}$-fertilizer rate application. Another research conducted by Boateng et al. (2006) also found that the genetic biomass plant background, the period when samples are taken and the growing environment, influence the lignin content in plants. Higher lignin component of Kemenyan Toba originated from North Tapanuli showed the prospective utilization of this wood as construction wood materials as that stated previously by Iswanto et al. (2016).

\section{Holocellulose}

The average of holocellulose content in this study was presented in Figure 3. Rowell (1984) stated that holocellulose is total polysaccharide contained in wood. Based on Figure 3, trend of holocellulose content increased from bottom to the top for Kemenyan Toba originated from North Tapanuli. Similar study also conducted by Latib et al. (2014). This higher of holocellulose content on the top position in stem was due to the low $\alpha$-cellulose and high hemicellulose content. According to Panshin and Carl de Zeuw (1980) hemicellulose content of wood varied from 40 to $80 \%$. Meanwhile, Rowell (2005) states that holocellulose in wood is generally $65-70 \%$ based on dry weight of wood. In this study, the average value of holocellulose from Pakpak Bharat was $69 \%$, and North Tapanuli was 52\%. The high level of holocellulose indicates that the yield of pulp production will be high.

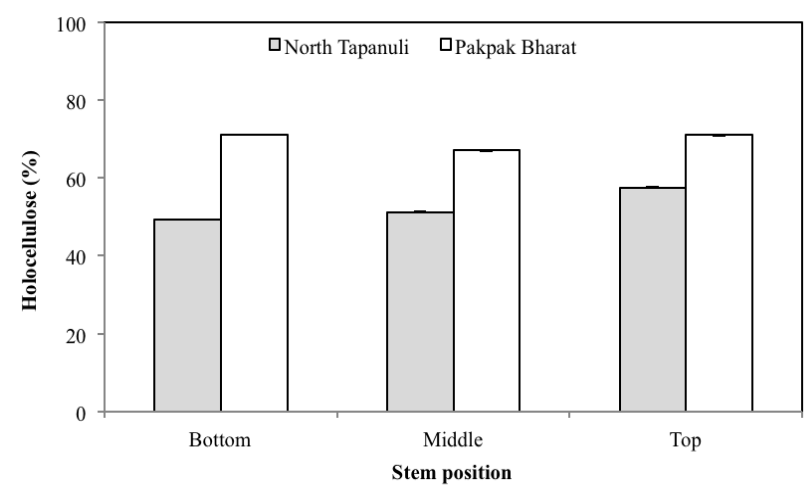

Figure 3. Holocellulose content of kemenyan from North Tapanuli and Pakpak Bharat Districts, North Sumatra, Indonesia based on stem position

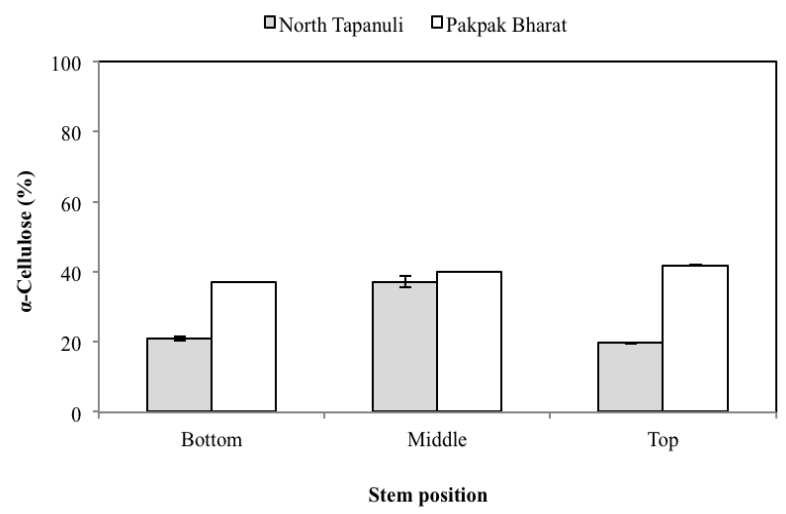

Figure 4. $\alpha$-Cellulose content of kemenyan from North Tapanuli and Pakpak Bharat Districts, North Sumatra, Indonesia based on stem position

\section{Alpha-Cellulose ( $\alpha$-Cellulose)}

The average of $\alpha$-Cellulose content in this study was presented in Figure 4. Alpha cellulose is insoluble cellulose in $17.5 \% \mathrm{NaOH}$ solution, the basic material of alpha cellulose is glucose. Glucose molecules connect to each other to form molecular chains of cellulose (Dumanauw 1982). Based on Figure 4, the $\alpha$-Cellulose content of Kemenyan wood from North Tapanuli was lower than Pakpak Bharat. Fengel and Wegener (1984) stated that generally, the alpha cellulose production depended on wood species and especially on the isolation and determination processes. According to Haygreen and Bowyer (1982), many factors cause variation in type, number, size, shape, physical structure, and chemical composition of wood elements. Sjostrom (1981) stated that cellulose content ranges from 40 to 50\%. Casey (1960) indicated that cellulose content in wood could be used to estimate the amount of pulp yield produced in the pulping process, where the greater of cellulose content in wood results in the greater of yield pulp. Overall, the average value of $\alpha$-Cellulose from Pakpak Bharat was 39\%, and North Tapanuli was $26 \%$. Based on the obtained results, $\alpha$ Cellulose content of Kemenyan wood from both locations was classified into low category. 


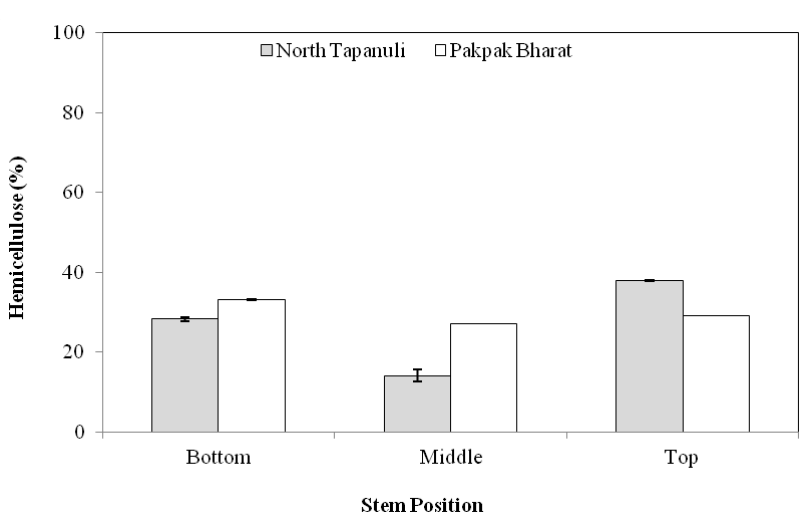

Figure 5. Hemicellulose content of kemenyan from North Tapanuli and Pakpak Bharat Districts, North Sumatra, Indonesia based on stem position

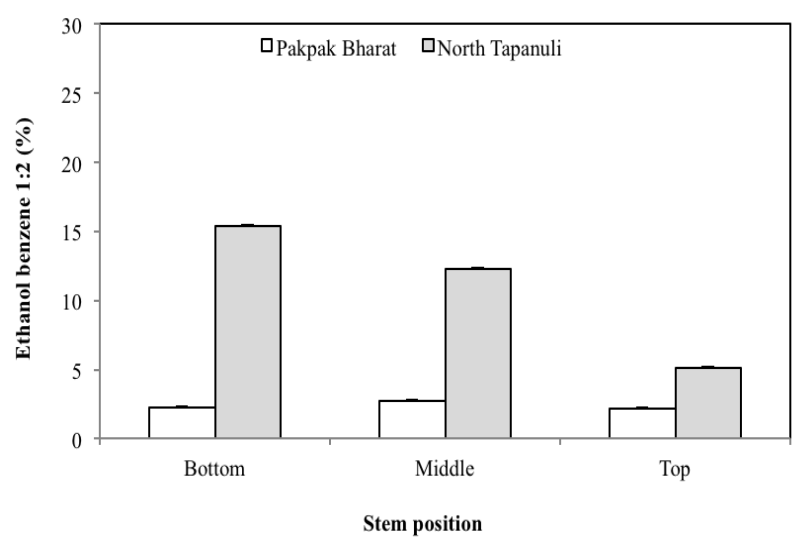

Figure 6. Extractive content in 1: 2 ethanol benzene of kemenyan from North Tapanuli and Pakpak Bharat Districts, North Sumatra, Indonesia based on the stem position

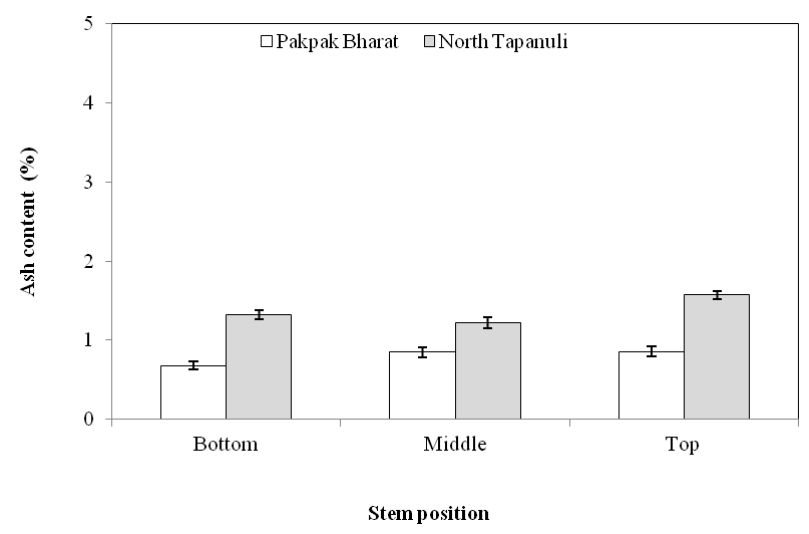

Figure 7. The ash content of kemenyan from North Tapanuli and Pakpak Bharat Districts, North Sumatra, Indonesia based on stem position.

\section{Hemicellulose}

The average of hemicellulose content in this research was shown in Figure 5. Hemicellulose is a low molecular weight of polysaccharide found in the cell wall. Hemicellulose is different from cellulose because it has a shorter branch of molecular chain. Hemicellulose in hardwood is dominated by xylan with content from 25 to $35 \%$, whereas softwood is dominated by mannan with content between 15 and 25\% (Fengel and Wegener, 1984).

Based on Figure 5, the average value of hemicellulose from Pakpak Bharat was $29 \%$ and North Tapanuli was $26 \%$. The value of hemicellulose content of Pakpak Bharat was higher than North Tapanuli, it was due to the higher content of holocellulose for that region. Based on axial direction of stem, it could be seen that hemicellulose content of middle part was smaller than others in both locations. The tendency of varying hemicellulose content in wood is relatively small and not the same as hemicellulose types. Since it is known as hardwood, the hemicellulose consisted of glucuronoxylan and glucomannan (Sjostrom, 1981).

\section{Chemical constituents of non-structural wood \\ Extractive content in Ethanol Benzene}

The average extractive content in this research was presented in Figure 6. According to Figure 6, the extraction value in 1:2 extraction of ethanol benzene, Kemenyan wood from North Tapanuli was higher than that of Pakpak Bharat. This could be also seen from color of wood test sample (Figure 1), Kemenyan wood from North Tapanuli had a reddish brown color. According to Tsoumis (1991), the extractive content varied not only in different species but also in the same tree with different stem positions. Overall the extractive content in 1:2 ethanol benzene of Pakpak Bharat was $2 \%$, which was classified into medium while North Tapanuli was $10 \%$, which was classified into high category.

\section{Ash content}

Ash materials show the content of inorganic materials of wood, which are remained after the burning process of organic matter. Ash could be traced due to the presence of unburned compounds containing elements like calcium, potassium, magnesium, manganese and silicon (Bowyer et al., 2003). The average of ash content in this research was presented in Figure 7.

According to Figure 7 , the ash content of kemenyan from North Tapanuli is higher than that of Pakpak Bharat. Based on the stem position, ash content tended to increase from bottom to top. This possibility is due to the top position had a high portion of earlywood and sapwood. Sapwood is a living part of wood that is still carrying out physiological activities so that there are inorganic materials from the soil deposited in cell walls of sapwood (Yunanta et al., 2014). Overall, the average value of ash content for Pakpak Bharat was $0.7 \%$ and North Tapanuli was $1.37 \%$. Based on the obtained results, Kemenyan wood from both areas classified into medium category.

Our research pointed out that, Kemenyan Toba originated from North Tapanuli has higher lignin, extractive and ash content compared to Kemenyan Toba from Pakpak Bharat. Meanwhile, higher content of alpha cellulose, hemicellulose, and holocellulose was produced in 
that of Pakpak Bharat District. Based on their chemical constituent characteristics, Kemenyan Toba wood originated from North Tapanuli was good to be utilized as light construction materials while that originated from Pakpak Barat was good for pulp and paper raw materials.

\section{ACKNOWLEDGEMENTS}

We would like to express our sincere thanks to Directorate General of Higher Education-Ministry of Research, Technology and Higher Education, Republic Indonesia for supporting research fund through to Grant of Penelitian Dasar Unggulan Perguruan Tinggi (PDUPT) years of 2018 (No: 75/UN5.2.3.1/PPM/KP-DRPM/2018)

\section{REFERENCES}

Akiyama T, Goto H, Nawawi D, Syafii W, Matsumoto Y, Meshitsuka G. 2005. Erythro/threo ratio of b-O-4 structures as an important structural characteristic of lignin. Part 4: variation in the erythro/threo ratio in softwood and hardwood lignins and its relation to syringyl/guaiacyl ratio. Holzfor-schung 59: 276-281.

Anonim. 1976. Vademecum Kehutanan Indonesia. Direktorat Jenderal Kehutanan Departemen Pertanian. Jakarta. [Indonesian]

Blankenhorn PR, Bawersok TW, Kuklewski KM, Stimely GM. 1985. Effect of rotation, site, and clone on the chemical content of Populus hybrid. Wood Fiber Sci 17 (3): 351-360.

Boateng AA, Jung HGAdler PR. 2006. Pyrolysis of energy crops including alfalfa stems, reed canary grass, and eastern gamagrass. Fuel 85: 2450-2457.

Bowyer JL, Shmulsky, Haygreen JG. 2003. Forest Products and Wood Science - An Introduction. Fourth edition. Iowa State University, Iowa, USA.

Casey JP. 1960. Pulp and paper chemistry and chemical technology. Volume I. Pulping and Bleaching. Interscience, New York, USA.

Dumanauw JF. 1982. Mengenal Kayu. PT. Gramedia. Jakarta. [Indonesian]

Easty DB, Thompson NS. 1991. Wood analysis. In: IS, Lewin M, editor. International Fiber Science and Technology: Wood Structure and Composition. Marcel Dekker, New York, US.

Fengel D, Wegener G. 1984. Wood, Chemistry, Ultrastructure, Reactions. Waster \& Grugter, New York.

Haygreen JG, Bowyer JL. 1982. Forest product and wood science, An introduction. Iowa: Iowa State University Press.Hidayat A, Iswanto AH, Susilowati A, Rahmat HH. 2018. Radical scavenging activity of kemenyan resin produced by an Indonesian native plant, Styrax sumatrana. J Korean Wood Sci Technol 46 (4): 346-354.

Hidayat A, Iswanto AH, Susilowati A, Rachmat HH. 2018. Radical Scavenging Activity of Kemenyan Resin Produced by an Indonesian Native Plant, Styrax sumatrana. J Korean Wood Sci Technol 46 (4): 346-354.

Iswanto AH, Susilowati A, Azhar I, Riswan, Supriyanto, Tarigan JE, Fatriasari W. 2016. Physical and mechanical properties of local Styrax wood from North Tapanuli, in Indonesia. J Korean Wood Sci Technol 44 (4): 539-550.

Kiswandono AA, Iswanto AH, Susilowati A, Lumbantobing AF. 2016. Analysis of the content of cinnamic acid and phytochemical screening sap incense species of Bulu (Styrax benzoine var. Hiliferum) of North Tapanuli. National Seminar of Chemical Proceeding. Lombok 10-11 Agustus. [Indonesian].
Kholibrina CR, Aswandi, Susilowati A. Flowering and Fruiting Phenology of Kemenyan Toba in Aek Nauli Forest, North Sumatra. IOP Conf Ser. Environ Sci 122 (1): 012061. DOI: 10.1088/1755$1315 / 122 / 1 / 012061$

Latib NA, Tamat NSM, Kasim J. 2014. Physical and chemical properties of Kelempayan (Neolamarckia Cadamba Sp.) wood. Intl J Latest Res Sci Technol 3 (6): 215-219.

Panshin AJ, Cart De Zeuw. 1980. Textbook of wood technology. Mc. Graw-Hill Book Company, New York.

Pasaribu G, Jasni, Damayanti R, Wibowo S. 2013. Anatomical, physical and mechanical properties of Kemenyan Toba (Styrax sumatrana) and Kemenyan Bulu (Styrax paralleloneurus). J Penelitian Hasil Hutan 31 (2): 161-169.

Pasaribu G, Sipayung B, Pari G. 2007. Chemical component analysis of four endemic wood species from North Sumatra. J Penelitian Hasil Hutan 25 (4): 327-333.

Poiša L, Adamovičs A, Antipova L, Šiaudinis G, Karčauskienè D, Platače R, Žukauskaitė A, Malakauskaitė S, Teirumnieka Ē. 2011. The chemical content of different energy crops. Tehnoloģja Resursi: In: VIII starptautiskās zinātniski praktiskās konferences materiāili. I sējums. Rēzekne, pp. 191-196.

Rahmat HH, Susilowati A, Elfiati D, Hartini KS, Faradillah WN. 2017. Strong genetic differentiation of the endemic rosin-producing tree Styrax sumatrana (Styracaceae) in North Sumatra, Indonesia. Biodiversitas 18, (4): 1331-1335.

Rowel RM. 2005. Handbook of wood chemistry and wood composite. CRC Press, Boca Raton, USA.

Rowell RM. 1984. The Chemistry of Solid Wood. American Chemical Society, Washington, D.C.

Sjöström E. 1981. Wood Chemistry. Fundamentals and Applications. Academic Press, New York, USA

Stout A, Davis AA, Domec JC, Yang C, Shi R, King JS. 2014. Growth under field conditions affects lignin content and productivity in transgenic Populus trichocarpa with altered lignin biosynthesgis. Biomass Bioen 68: 228-239.

Susilowati A, Rahmat HH, Kholibrina CR, Ramadhani R. 2017a. Weak delineation of Styrax species growing in North Sumatra-Indonesia by matK+rbcLGene. Biodiversitas 18 (3): 1270-1274.

Susilowati A, Sri Harini K, Alvaroby M. 2017b. Propagation of valuable North Sumatera Benzoin (Styrax spp) using macrocutting technique. IOP Conf.Series: Materials Science and Engineering 180 (1): 012046. DOI: 10.1088/1757-899X/180/1/012046

Susilowati A, Rachmat HH, Kholibrina CR, Munthe MA. 2018. Phylogeny of kemenyan (Styrax sp) based on morphological character. IOP.Conf.Ser. Environ Sci DOI: 1): 012062. DOI :10.1088/1755-1315/122/1/012062

TAPPI. 2002. Technical Association of Pulp and Paper Industry T 211 om-02. Ash in , ood, pulp, paper and paperboard: c C.ustion at $525^{\circ} \mathrm{C}$ . TAPPI, Atlanta, USA.

TAPPI. 2007. Technical Association of Pulp and Paper Industry T 264 cm-07. Sampling and preparing wood for analysis. TAPPI, Atlanta, USA.

Tsoumis G. 1991. Science and Technology of Wood: Structure, Properties, Utilization. Van Nostrand Reinhold, New York, USA.

Widyastuti W. 1989. Perkembangan aromatherapy. Prosiding Simposium I Hasil Penelitian dan Pengembangan Tanaman Industri. Pusat Litbang Tanaman Industri. Caringin, Bogor 25-27 Juli 1989. [Indonesian].

Wise LE, Murphy M, D'Adieco A. 1946. Chlorite holocellulose, its fractionation and beating on summative wood analysis and on studies on the hemicelluloses. Paper Trade J 122: 35-43.

Yunanta RRK, Lukmandaru G, Fernandes, A. 2014. Chemical properties of Shorea retusa, Shorea macroptera, and Shorea macrophylla woods. Jurnal Penelitian Dipterokarpa 8 (1): 15-25.

Zhang P, Wu F, Kang X. 2015. Chemical properties of wood under strong genetic control than growth trait in Populus tomentosa Carr. Ann For Sci 72: 89-97. 